\title{
THE DISTRIBUTIONAL BURDEN OF TAXING ESTATES AND UNREALIZED CAPITAL GAINS AT THE TIME OF DEATH
}

\author{
James M. Poterba \\ Scott Weisbenner \\ Working Paper 7811 \\ http://www.nber.org/papers/w7811
NATIONAL BUREAU OF ECONOMIC RESEARCH 1050 Massachusetts Avenue Cambridge, MA 02138
July 2000

We are grateful to Jeffrey Brown for providing us with data on mortality rates, to Barry Johnson and Jacob Mikow for providing us with data on 1998 estate tax returns, to Thomas Barthold, Len Berman, William Gale, David Joulfaian, Alan MacNaughton, and Larry Ozanne for helpful discussions, and to the National Science Foundation (Poterba) for research support. Views expressed in this paper are those of the authors, and should not be attributed to any of the institutions with which they are affiliated.

(C) 2000 by James M. Poterba and Scott Weisbenner. All rights reserved. Short sections of text, not to exceed two paragraphs, may be quoted without explicit permission provided that full credit, including $\mathbb{C}$ notice, is given to the source. 
The Distributional Burden of Taxing Estates and Unrealized Capital

Gains at the Time of Death

James M. Poterba and Scott Weisbenner

NBER Working Paper No. 7811

July 2000

JEL No. H24

\begin{abstract}
$\underline{\text { ABSTRACT }}$
The 1998 Survey of Consumer Finances provides information on household wealth ownership that can be used to estimate the effect of changing the Unified Estate and Gift Tax Credit on estate tax revenues. The survey also includes data on the prices at which assets were purchased, along with information on their market values. This makes it possible to compare the revenue yield and the distributional consequences of taxing estates with those of taxing unrealized capital gains on assets held by individuals who die. This paper uses data from the Survey of Consumer Finances to estimate the revenue effects of changes in both estate tax provisions and capital gains tax rules. It finds that among those with small estates ( $\$ 1$ million or less), taxing capital gains at death would collect more revenue than the current estate tax from roughly half of the decedents. For those with larger estates, replacing the estate tax with a tax on unrealized gains at death would result in a substantial reduction in total tax payments. The revenue estimates and distributional analyses assume no change in the current capital gains realization behavior of taxpayers, even if the tax law changes. This is an important limitation, and the paper notes several directions for further research that might help to relax this assumption.
\end{abstract}

James M. Poterba

Department of Economics

MIT

E52-350

50 Memorial Drive

Cambridge, MA 02142

and NBER

(617)253-6673

poterba@mit.edu
Scott Weisbenner

Federal Reserve Board of Governors

Washington, DC 20551

(202)452-3000

scott.j.weisbenner@frb.gov 
"Basis step-up at death" is an important provision of the current income tax law that affects the total tax burden on some types of capital income. If an individual holds appreciated capital assets at the time of her death, those who inherit these assets receive them with a tax basis equal to their market value at the time of the decedent's death. Such basis step-up extinguishes capital gains tax liability for gains that occurred during the decedent's lifetime. There are no precise estimates of the fraction of capital gains that are held until death and that consequently qualify for basis step-up under the income tax. Researchers have long suspected that this fraction is substantial. Bailey (1969) suggested that the basis step-up provision could render the effective tax rate on capital gains only half the statutory rate on realizations. Revenue estimates by the Joint Committee on Taxation, reported in Congressional Budget Office (2000), suggest that eliminating basis step up at death and taxing unrealized capital gains at death would raise federal personal income tax liabilities by $\$ 10.5$ billion in 2002 .

The recent debate on "death taxes" has sometimes focused on the combined effect of the estate and income taxes. Poterba (2001) and others explain that high net worth individuals face a tradeoff between estate and income taxation if they hold appreciated assets. If they hold their assets until death, they will avoid capital gains tax liability, at a maximum federal marginal tax rate of 20 percent, but they will face estate taxation. However, if high net worth individuals sell their assets and realize gains before they die, then they will be liable for income taxes, but they may be able to pursue estate-planning strategies that reduce their taxable estate. Since the marginal estate tax rate peaks at 60 percent, in some cases it may pay to realize gains before death and to reduce estate taxes. The interaction between income and estate taxes is evident in some proposals that call for 
reducing estate tax rates, or for eliminating the estate tax, in tandem with eliminating the basis stepup at death provisions in the federal income tax.

These reforms are sometimes paired to reduce the revenue cost of eliminating the estate tax. The revenue generated by taxing capital gains at death is very unlikely to fully offset the revenue loss from estate tax elimination. Estate tax rates are higher than tax rates on long-term capital gains, and the unrealized gains on assets held by decedents are only a fraction of their total wealth. Taxing unrealized capital gains at death would, however, raise revenue from a set of taxpayers who do not currently pay estate tax. These are decedents whose net worth falls below the estate tax threshold, but who have appreciated capital assets when they die.

In this paper, we use data from the 1998 Survey of Consumer Finances (SCF) to analyze the distributional effects of reducing estate taxes and taxing unrealized capital gains on assets that are held until death. We summarize the tax collected from current estate tax payers as well as the tax that might be paid by decedents who do not currently face the estate tax. We also explore the patterns in tax burdens that would arise if expanded capital gains taxation wholly or partially replaced estate taxation.

The paper is divided into five sections. The first describes the current estate tax law, prospective changes, and the current capital gains tax rules. The second section introduces the Survey of Consumer Finances and explains our procedure for estimating each household's expected estate tax burden and the expected burden of capital gains taxation at death. Section three reports our estimates of how changing the threshold for estate taxation, for example raising this threshold to $\$ 1$ million or more, would affect federal estate tax revenues. The next section presents data on 
the distribution of unrealized capital gains and total wealth among decedents, and it compares the distribution of taxes on estate value versus taxes on unrealized capital gains. A concluding section discusses our use of a "no behavioral response" scenario, and it suggests a number of dimensions along which taxpayers might respond to legislative changes like those considered here. Trying to measure such behavioral responses, and building them in to revenue estimates and distributional analyses, is a natural direction for future work.

\section{The Current U.S. Estate Tax and the Tax Treatment of Capital Gains at Death}

Both the estate tax and the income tax treatment of capital gains have been subject to recent changes. The Taxpayer Relief Act of 1997 (TRA97) raised the threshold on the value of an estate that a decedent could leave without facing estate taxation, and it also reduced the tax rate on longterm capital gains. This legislation also began the phase-in of various tax rate changes that will not be fully effective until 2006. These changes further affect the estate tax rules and the income tax treatment of long-term capital gains. This section summarizes current tax rules with particular emphasis on the rules in place in 1998, when the survey data that we analyze were collected.

\subsection{Current Estate Tax Rules}

The United States currently has a unified estate and gift tax, which means that a tax is levied on the value of assets transferred at the taxpayer's death, plus the value of taxable gifts that were made during the decedent's lifetime. These rules do not apply to inter-spousal gifts and bequests; such transfers are exempt from estate taxation. In practice, this means that when one spouse in a married couple dies, there is relatively little estate tax due, but when the surviving spouse dies, there 
is often a substantial tax burden.

The estate tax is highly progressive. Table 1 shows the set of tax rates that applied to decedents who died in 1998. Each individual receives a credit against lifetime estate and gift taxes. Between 1986 and 1997, each taxpayer received a credit of $\$ 192,800$, which was precisely the amount of estate tax liability on an estate of $\$ 600,000$. TRA97 enacted a set of changes in the estate and gift tax credit that will raise the size of estates that are exempt from tax to $\$ 1$ million beginning in 2006. Table 2 shows the time path of the effective estate tax threshold for the 19972006 period (see Joulfaian (1998) for a longer time span). TRA97 also included a special provision for estates that include family-owned businesses. Up to $\$ 675,000$ of the value of a family-owned business became exempt from estate taxation effective January 1, 1998.

Although Table 1 shows tax rates for 1998 estates valued at less than $\$ 625,000$, decedents whose estates and cumulated lifetime taxable gifts are valued at less than this amount do not pay any estate tax. The value of the Unified Estate and Gift Tax Credit exceeds their estate tax liability. For decedents whose taxable estates were valued at more than $\$ 625,000$, the marginal estate tax rate on the 625,001 st dollar of taxable estate is 37 percent. The highest statutory marginal estate tax rate is 55 percent. As a result of a surcharge that phases out the infra-marginal estate tax rates of less than 55 percent, however, the highest effective marginal estate tax rate is 60 percent on estates valued at between $\$ 10$ million and $\$ 17.184$ million.

There are various ways for high net worth individuals to reduce the effective burden of the estate tax. For those with levels of wealth that would expose them to estate taxation, but that are not much greater than the estate tax threshold, there are opportunities to make tax-free gifts. Each 
individual may make a tax-free gift of $\$ 10,000$ per year per recipient. This means that a married couple can transfer $\$ 20,000$ per year to each child, grandchild, or other beneficiary. The $\$ 10,000$ annual exemption has been indexed for inflation since 1999. There are also more complex estate planning strategies that might be used by higher net worth households. These include the creation of trusts that shelter assets from estate taxation, the creative use of financial products such as life insurance, and the use of multi-tiered transfers for family property such as businesses that permits use of "minority discounts" in valuing the assets being transferred. Cooper (1979) is a classic summary of various strategies for estate tax avoidance; Drew and Johnston (1996) have more recently described some popular techniques. Schmalbeck (2000) presents an overview of current estate-planning strategies.

The current project focuses exclusively on federal estate taxes, although there are also taxes in many states on inheritances, gifts, and estates. These taxes together raise about one third of the revenue raised by the federal estate tax. In most cases state death taxes are creditable against federal estate tax liability for those taxpayers with federal estate tax liability, although not all decedents whose estates pay state death taxes pay federal estate taxes. One question that might arise if the federal estate tax were reduced or eliminated, but which we do not consider, is how states would modify their death taxes, and how this would affect the total burden of estate taxation.

\subsection{Current Tax Rules on Long-Term Capital Gains}

Since 1997 , long-term capital gains have been taxed at a maximum statutory tax rate of 20 percent. Long-term gains are defined as gains on assets that have been held for at least twelve months. (During 1998, the year when the Survey of Consumer Finances was carried out, long-term 
gains were defined as gains on assets held more than 18 months. There was an "intermediate gains" category for gains on assets held between 12 and 18 months.) Under current law, the marginal rate on long-term gains will decline to 18 percent, effective in 2005 , for assets that have been held for at least five years. Basis step-up at death has been a long-standing feature of the income tax rules that apply to capital gains. Congress approved a provision that would carry over the decedent's basis in assets in the Tax Reform Act of 1976, but the provision was repealed before it could take effect.

One important class of capital gains, those on principal residences, receive special treatment under the current capital gains tax. Homeowners may exclude $\$ 250,000$ of gains, or $\$ 500,000$ on joint returns, from capital gains tax calculations. This provision eliminates capital gains tax liability for many taxpayers whose only appreciated asset is their home.

\section{Using the Survey of Consumer Finances to Estimate Estate Tax Burdens}

Our empirical analysis uses information reported in the 1998 Survey of Consumer Finances, along with assumptions about prospective mortality of each survey household. The Survey of Consumer Finances (SCF), a stratified random sample of U.S. households, is described in detail by Kennickell, Starr-McCluer, and Surette (2000). The survey includes a random population sample, as well as a sample that is drawn from information on tax returns and that over-weights households with high levels of capital income. The SCF is generally regarded as the best data available on the asset and liability positions of U.S. households. It also provides the best information on the highnet-worth segment of the population, the segment most affected by estate tax reform.

The SCF sampled 4305 households in its 1998 survey. Table 3 presents the net worth 
distribution of the survey respondents. One fourth of the households have net worth of over a million dollars, and 245 households have net worth in excess of \$20 million. The wealthiest households are typically married couples. The maximum net worth in the sample is $\$ 501$ million, which corresponds to the net worth threshold that a household needed to be included in the Forbes 400 richest Americans in 1998. While data on the upper tail of the net-worth distribution is sparse, the SCF provides at least some coverage of all but the highest of high-net-worth households.

Since the SCF is a survey of individuals who are alive, and the estate tax applies to individuals when they die, it is necessary to combine data on mortality rates with information on wealth holdings in order to estimate estate tax liability. Poterba (2000) explains that there are two sets of mortality rates that could be used for this purpose. The first is the population life table, reported by the Social Security Administration Office of the Actuary. This life table applies to individuals chosen randomly from the population at large. Various studies, most recently Attanasio and Hoynes (2000), suggest that high income and high net worth households have lower mortality rates than their lower-income counterparts, so the population mortality table may not accurately describe the mortality rates of those who are subject to the estate tax.

An alternative mortality table that may describe the mortality rates facing the high-net-worth households better than the population mortality table is the Individual Annuitant Life Table, which is described in Mitchell, Poterba, Warshawsky and Brown (1999). It describes the mortality experience of individuals who purchase single-premium annuities from life insurance companies. These individuals typically have sufficient accumulated resources to purchase policies with initial premiums of between $\$ 50,000$ and $\$ 100,000$, so they are from the upper tail of the wealth 
distribution. They may also have some private information suggesting longer-than-average longevity prospects, although as Finkelstein and Poterba (2000) explain, it is difficult to measure the degree of adverse selection. Age-specific mortality rates in the individual annuitant table are between 25 percent and 35 percent lower than those in the population life table.

One counter-argument to the use of the annuitant mortality table recognizes that most estate tax paying decedents are single. Single individuals have higher mortality rates than married individuals, so the annuitant mortality table may understate actual death rates for potential estate tax payers. Eller, Erard, and Ho (2000) note that assumptions about the mortality rate of potential estate tax decedents have first-order effects on revenue estimates. Further work is needed to calibrate the mortality table for wealthy individuals who may face estate tax liability.

We consider two different algorithms in analyzing estate tax revenues. The first assumes that estate tax liability for married couples is triggered only when the second spouse dies, while the second assumes that even the first to die may leave a taxable estate. To illustrate our procedures, we first describe our "second-to-die" algorithm. We use the annuitant mortality table to estimate the probability that each household dies in a given year. The mortality probability for the household is $\mathrm{q}_{\mathrm{h}}$. For households with only one member, $\mathrm{q}_{\mathrm{h}}$ is just the probability of dying during the year: it depends on the age and sex of the individual. For married couples, in the "second-to-die" algorithm, we assume that when the first spouse dies, all assets are bequeathed to the spouse, and that there is correspondingly no estate tax liability. In this case, for married couples the relevant mortality rate for triggering estate tax liability $\left(\mathrm{q}_{\mathrm{h}}\right)$ is the probability that both spouses die within the year. We calculate this probability assuming that the mortality rates of the two members of the 
married couple are independent; there is weak evidence of a positive correlation in the mortality experience of couples.

Although many married couples appear to use estate plans that defer all estate taxes until the death of the second spouse, this is not necessarily the best strategy from the standpoint of minimizing estate taxes. Schmalbeck (2000) notes that this approach does not take advantage of the progressivity of the estate tax rate schedule. If a couple splits ownership of all assets, and the first-to-die bequeaths none of his or her assets to the surviving spouse, then the couple will be able to utilize two $\$ 625,000$ exemptions and will also pass more of their wealth through the lower rate brackets of the estate tax. The possibility that some couples follow this strategy motivates our second algorithm for estimating the estate taxes of married couples. It assumes that assets are divided equally between spouses when one spouse dies. Thus, half of the married couple's assets will be subject to the estate tax when the first spouse dies. In this case, our estimate of estate tax liability for married couples is approximately equal to the sum of the mortality probabilities for the two members of the couple, times the estate tax due on half of their household net worth. We also add the (smaller) probability that both spouses die, times the estate tax due on their entire net worth.

Our measure of net worth, the base to which the estate tax applies, includes the face value of life insurance policies. Including insurance proceeds in the estate tax base brings a number of younger households in the SCF into the set of potential estate tax payers. These households typically have very low probabilities of dying so their expected estate tax is quite low. In codifying the estate tax function in equation (1), we recognize a number of detailed features of the estate tax, such as the $\$ 675,000$ exemption for business assets. 
One potential limitation of our approach is our use of the reported value of assets in the $\mathrm{SCF}$, rather than a measure that allows for any under-valuation of assets for the purposes of estate taxation. The practice of invoking "minority discounts" in valuing some types of assets, which is discussed in Schmalbeck (2000), is likely to result in our estimates overstating the estate tax that would be collected for particular assets. It is also possible that there is another set of biases that operate in the opposite direction. If some SCF respondents omit assets when they respond to the survey, or if they use asset valuations that are potentially out of date, this may result in undervaluation of gross estates relative to their actual value.

We use an approach similar to that in equation (1) to estimate the expected capital gains tax liability that would be associated with taxing each household's unrealized capital gains at the time of death. In this case, in place of net worth for household $h$, we focus on our estimate of the stock of unrealized capital gains $\left(\mathrm{UG}_{\mathrm{h}}\right)$ held by household $\mathrm{h}$. We then calculate

$$
\mathrm{E}(\text { Tax on Capital Gains at Death })=\mathrm{qh}_{\mathrm{h}}{ } \tau_{\mathrm{cg}}\left(\mathrm{UG}_{\mathrm{h}}\right)
$$

where $\tau_{\mathrm{cg}}()$ denotes the capital gains tax schedule. Under current tax law, the tax rate on capital gains at death is assumed to be $20 \%$. Note that for each household in the SCF, our estimate of the ratio of the expected estate tax and the expected capital gains tax if unrealized gains were taxed at death is unaffected by the mortality rate. In calculating the revenue from taxing capital gains at death, we assume that when one spouse in a married couple dies, all assets pass to the surviving spouse and that there is no capital gains tax liability. One could alternatively, although we do not, assume a more complicated pattern of gain recognition associated with death of the first spouse. The SCF provides data on the composition of a household's net worth. Survey respondents 
are asked the value of their holdings across many asset types such as real estate, stocks, bonds, and business interests. Households also provide the purchase price or basis for certain assets. For assets that are inherited from someone other than a spouse, the respondent reports the market value of the asset when it was received as the basis. The respondent is asked how much his non-pension plan holdings of publicly traded stock and mutual funds have gained in value since they were obtained. The SCF also records both the net worth of the household's share of a business as well as the cost basis for tax purposes for all businesses in which the household has either an active or nonactive management role. Finally, each survey respondent is asked both the current value and what he originally paid for his primary residence as well as all other real estate holdings.

We can use this information to directly calculate a household's unrealized capital gains held in publicly traded stock, mutual funds, real estate, and businesses. Assets such as savings accounts and certificates of deposit do not generate capital gains. The purchase price or basis is not reported for such assets as bonds, vehicles, and collectibles that may have undergone a capital gain or loss. Throughout the paper, we assume that these assets have no accrued capital gains. This group of assets constitutes less than one tenth of aggregate net worth, and only $6 \%$ of total estate value. We exclude assets held in retirement accounts such as IRAs or 401(k)s when we calculate unrealized capital gains, since the payouts from those accounts are taxed as ordinary income.

\section{Federal Estate Tax Liability For Different Tax Thresholds}

Johnson \& Mikow (2000) report that estate tax returns filed in 1998 generated \$20.4 billion in revenue. Actual federal receipts from the estate tax for fiscal year 1999 (this would primarily be 
from 1998 decedents) were $\$ 28$ billion. Table 4 reports our estimates of estate tax revenue from 1998 decedents using the SCF and the mortality assumptions discussed earlier. Our estimates assume that each estate claims the average value, for 1998 taxable estate tax returns in its gross estate class, of funeral expenses, executor's commissions, lawyer's fees, and charitable deductions. This leads to an estimate of gross federal estate tax liability for each estate, which is then reduced by the average level of state death tax credits for taxable estates in the decedent's gross estate valuation class.

Calculating the estate tax revenue from single households is straightforward, and we estimate that the federal estate tax collected $\$ 16.0$ billion from these households in 1998. Estate taxes on returns filed in 1998 by single decedents totaled $\$ 16.7$ billion; this is primarily from 1997 decedents. The estimated distribution of the tax across broad estate groups matches fairly well that of single decedents who filed estate tax returns in 1998. Data from the Internal Revenue Service show that single decedents who filed 1998 returns with gross estates valued at $\$ 600,000$ to $\$ 1$ million paid $\$ 0.88$ billion, those with $\$ 1$ to 5 million paid $\$ 7.86$ billion, $\$ 5-10$ million paid $\$ 2.84$ billion, and estates exceeding \$10 million paid \$5.11 billion. Our 1998 SCF-based estimates suggest that single estate tax filers with estates of $\$ 600,000$ to $\$ 1$ million paid $\$ 0.24$ billion in estate tax, those with estates of $\$ 1$ to $\$ 5$ million paid $\$ 8.22$ billion, those with $\$ 5$-10 million paid $\$ 3.16$ billion, and those with gross estates greater than $\$ 10$ million paid $\$ 4.36$ billion.

We now consider our two alternative approaches to estimating the estate tax liability of married couples. The first, which assumes that the first-to-die spouse bequeaths everything to the surviving spouse, implies that there will be no estate tax liability until the surviving spouse dies. 
The first two columns of Table 4 show that under this assumption, we estimate that only $\$ 0.6$ billion of estate tax would have been collected from deaths of married couples during 1998. This reflects the small probability that both spouses die in the same year. The last two columns of Table 4 present estimates of estate tax revenue from married households under the alternative assumption that the first spouse to die leaves half of the couple's assets as an estate. Estimated tax revenue from deaths in married couples now rises to over $\$ 26$ billion. These divergent estimates underscore the importance of determining how deaths in married couples translate into taxable estates.

Table 5 sheds some light on the estate tax planning of married couples. On estate tax returns filed in 1998, only $13 \%$ of married decedents with gross estates valued in excess of $\$ 600,000$ paid any estate tax, whereas over $75 \%$ of single decedents with gross estates valued in excess of $\$ 20$ million did so. Only half of married decedents with estates valued between $\$ 10$ and \$20 million paid any estate tax. Further, while the gross estate value of married decedents is roughly the same as that for single decedents, married decedents accounted for only $18 \%$ of total estate tax revenue in 1998. Johnson and Mikow (1999) report similar results when examining the returns of 1995 decedents. Thus, it seems that the majority of couples do not employ simple tax avoidance techniques, such as having the first-to-die pay some estate tax, which could reduce the couple's total estate tax. This finding parallels results in Poterba (2001) on the limited use of taxfree gifts as a strategy for reducing estate tax liability.

To use the data in Table 5 to sharpen our estimates of the estate taxes due when one member of a married couple dies, we make an important simplifying assumption. We assume that married couples either pass all of their assets to the surviving spouse, as our first algorithm 
assumes, or that they follow the principle of dividing their assets equally between spouses, with each spouse bequeathing half of the couple's net worth at the time of death. The latter assumption corresponds to our second algorithm. We then assume that the fraction of returns in each gross estate class that pay any estate tax, as in Table 5, equals the fraction of married couples in that net worth category that follows the equal division rule. Thus, we assume that 74.9 percent of all married couples with more than \$20 million in household net worth follow the equal division strategy. Using this assumption, we estimate total 1998 estate tax revenue of $\$ 27.4$ billion. This equals taxes from single decedents, plus the weighted average of the two estimates for married couples presented in Table 4 . We also considered modeling the probability that a married decedent bequeaths nothing to his or her spouse as a function of the ratio of the average tax rate on estates of married decedents and on single decedents. This approach yields an estimate of total estate tax revenue of $\$ 22.3$ billion.

The foregoing estimates describe the potential estate tax liability of households in the 1998 Survey of Consumer Finances. This survey, however, does not include the highest net worth households in the U.S. economy. By excluding the wealthiest segment of the population from its sampling, largely because they might be identified based on other publicly-available information, the SCF in effect enables us to estimate the estate tax burden on the population with wealth below the level of the Forbes 400 .

Since the Forbes 400 members are publicly identified, we can augment the SCF data with information on the wealth holdings, and deaths, of this group. Table 6 summarizes the number of members of the Forbes 400 who died in recent years, along with the net worth of these decedents. 
In the average year between 1995 and 1998, seven members of the Forbes 400 died. The net worth of these decedents varied substantially, from $\$ 5.9$ billion in 1997 to $\$ 20.3$ billion in 1998 . To translate the wealth of the Forbes 400 decedents into estate taxes, we consider the ratio of estate taxes to the gross estate value for married and single 1998 decedents with estates valued at $\$ 20$ million or more. This ratio is 0.285 for single decedents and 0.094 for married decedents. Applying these ratios to the net worth of the 1998 Forbes 400 decedents would imply an additional $\$ 2.3$ billion in estate taxes, while applying it to the 1997 decedents would generate $\$ 0.7$ billion in additional taxes. These values suggest that the divergence between actual estate tax revenue as reported by the IRS, and our estimate of estate tax liability, can be attributed in part to the absence of very high net worth households in the Survey of Consumer Finances.

Our SCF-based estimate of estate tax liability in Table 4 corresponds fairly closely to the actual estate tax liability in recent years, particularly once we recognize the additional contribution of the highest net worth households. The net federal estate tax paid by 1998 filers was $\$ 20.4$ billion, and receipts during fiscal year 1999 were about \$28 billion. Our estimates suggest estate tax revenue of $\$ 16$ billion from single households in 1998, and between $\$ 6$ and $\$ 11$ billion from married households. Adding Forbes 400 decedents boosts the estimated tax collection to a total between $\$ 23$ and $\$ 30$ billion.

The similarity of our estimate of total estate tax liability, and actual aggregate revenues, stands in contrast to Wolff's (1996) related analysis. He argues that an algorithm similar to ours yields a projected estate tax liability based on the 1992 SCF of $\$ 44$ billion, compared with $\$ 10.5$ billion in actual estate tax collections from 1992 decedents. Sullivan (2000) reports calculations in 
a similar vein based on the 1998 Survey of Consumer Finances.

There are a number of potential explanations for the divergence between our results and those in other studies. One is that Wolff (1996) uses the population mortality table, which yields a higher estimate of intergenerational transfers and estate tax liability than the annuitant mortality table that we use. A second is that he relies on a re-weighted version of the 1992 Survey of Consumer Finances, with weights that generate a larger total wealth stock (hence larger bequests) than the public use weights, particularly among high-net-worth households.

When we apply the algorithm described by equation (1) to the $1995 \mathrm{SCF}$, we find the expected estate tax liability for the year is $\$ 14.4$ billion, while actual estate tax revenues for 1995 decedents were $\$ 14.3$ billion ( $\$ 11.8$ billion for non-married decedents). The very close similarity of the estimate and actual is probably coincidence. For 1992, our SCF-based estimate of estate tax liability is $\$ 7.9$ billion, while actual taxes for 1992 decedents were $\$ 10.5$ billion ( $\$ 8.6$ billion for non-married decedents). For both years, it seems that the expected tax generated by our algorithm is similar, to a first order, to actual estate tax revenue. Further analysis of the source of differences across years is left to future research.

Given the rough success of our algorithm in tracking federal estate tax revenues under current and recent estate tax rules, we used it to consider the impact of several counterfactual assumptions about estate and gift tax credits. Table 7 reports our calculations for a variety of different exemptions. The estimates in the top panel are based on a weighted average of our two approaches to treating married couples. The middle and bottom panel present results first under the assumption that married decedents leave everything to their surviving spouse, and then under the 
assumption that married couples follow an equal division of estates with no bequest to the surviving spouse. We assume that the fraction of married decedents that follow the strategy in the bottom panel corresponds to the fraction of returns by married decedents in each gross estate class that pay any tax (presented in Table 5). The fraction of married decedents that leave everything to the surviving spouse, as the middle panel in Table 7 assumes, is assumed to be the fraction of returns in each gross estate class that pay no tax.

The first column in Table 7 presents revenue estimates under the actual 1998 law, namely assuming a $\$ 625,000$ exemption. We estimate a total federal estate tax collection of $\$ 27.4$ billion. This value does not include any revenue that might be collected from the Forbes 400 decedents, which could yield an additional $\$ 2.3$ billion based on our estimate above.

To illustrate the effect of changing exemption levels, we focus on the weighted average case. If the exemption had been $\$ 1$ million in 1998, this would have reduced our estimate of revenues from $\$ 27.4$ billion to $\$ 23.6$ billion. Revenues would drop to $\$ 12.8$ billion if the exemption level was raised further to $\$ 3$ million. Exempting the value of the principal residence (up to $\$ 1$ million) from the estate tax would reduce estimated tax receipts by about an eighth. Expanding the deduction for an actively managed business would have a slightly more modest effect on estate tax revenue. The middle and bottom panel of Table 7 show that total revenues are lower (higher) when we assume that married decedents leave everything (nothing) to the surviving spouse, but the direction of the effects are similar. 


\section{Taxing Capital Gains at Death vs. Taxing Estates}

We now consider the comparative distributional burdens of the current estate tax and a capital gains tax levied on all unrealized gains at the time of death. We begin by presenting summary information on the importance of unrealized capital gains in the portfolios of decedents, and we then compare the tax payments of decedents under different tax rules. Throughout this section, we will assume that the estate tax and the tax on unrealized capital gains for married couples are triggered only when the second spouse dies. In other words, we assume that transferring assets to a spouse does not generate a capital gains tax liability, but that carryover basis rules apply to such transactions. Since our tabulations are based on the SCF, they once again only apply to households with net worth below the level of the Eorbes 400 .

The type of policy change that we consider below is similar to one enacted in Canada nearly three decades ago. In 1972, the Canadian federal estate tax was eliminated, and at the same time a capital gains tax was adopted for gains on assets transferred at death. Bossons $(1972,1974)$ presents a detailed description of the Canadian reforms, and the contemporaneous estimates of the revenue effects of this policy change.

\subsection{Unrealized Capital Gains as a Share of Net Worth}

The Survey of Consumer Finances data enable us to estimate the unrealized capital gains in household portfolios, and to compare this information with our estimate of household net worth. Table 8 presents summary information. The first row shows the total value of estates for households in different net worth categories, while the second row shows the corresponding unrealized capital gains for households in different categories. For all households, expected 
unrealized capital gains at death total $\$ 42.8$ billion, or 36 percent of the total expected value of estates. There is only a weak association between the ratio of unrealized gains to estate value and estate size. The values of this ratio are near one third for most net worth categories. At the highest level, for those with estates worth at least \$10 million, unrealized gains represent 56 percent of the value of estates.

Table 8 also shows the distribution of asset holdings across different net worth categories. It demonstrates the dramatically different importance of owner-occupied real estate for those at low net worth levels and those at higher levels. For households with net worth of less than $\$ 250,000$, primary residences account for nearly sixty percent of total assets, while for those with net worth of more than $\$ 10$ million, this percentage drops to only three percent. The decline in the importance of primary residences is matched by a sharp wealth-related increase in the importance of businesses in which the decedent was an active participant. Such businesses account for nearly half of the assets of those with net worth of at least $\$ 10$ million, while they account for less than one percent of the assets of those with net worth of less than $\$ 1$ million. The composition of capital gains across asset types matters for estate tax liabilities, since capital gains on owner-occupied housing are in many cases taxed at a lower rate than other capital gains.

Within the stock of unrealized capital gains, there are also significant differences in composition across net worth categories. Primary residences account for more than nine-tenths of the unrealized capital gains of households with net worth of less than $\$ 500,000$, while they account for less than four percent of unrealized gains for those with net worth of $\$ 10$ million and above. Similarly, unrealized capital gains on active businesses account for more than seventy 
percent of the unrealized gains of households in the highest net worth category, while they account for only a negligible fraction of the unrealized gains for those in lower net worth strata. The ratio of unrealized capital gains on stock and mutual fund holdings to total gains is also substantially higher for the wealthy.

Table 9 presents more direct evidence on the importance of unrealized gains relative to estate value. The table shows the fraction of decedent households, by net worth category, with unrealized capital gains of less than 25 percent, 25 to 50 percent, 50 to 75 percent, and more than 75 percent of their net worth. Half of all decedents report unrealized capital gains of less than one quarter of their net worth. Only three tenths report unrealized capital gains of at least half the value of their net worth, and 13 percent report unrealized gains that equal at least three quarters of their net worth. Households with more than three quarters of their net worth in the form of unrealized gains are concentrated in the less than $\$ 1$ million and more than $\$ 10$ million net worth categories.

Table 9 provides some indication of the dispersion in income tax liabilities that would result from taxing unrealized capital gains at death. There is wide dispersion in unrealized gains as a share of net worth. Since net worth is to a first approximation the basis for estate taxation, there are likely to be substantial differences across households with similar net worth in the tax payments under an income tax that taxes unrealized gains at death. The composition of unrealized capital gains across asset holdings will also be a key determinant of tax burdens, since some types of capital gains are taxed more lightly than others. 


\subsection{Revenue Effects of Alternative "Death Tax" Policies}

The information summarized in Tables 8 and 9 permits calculation of the revenue effects, and the potential distributional effects, of various taxes on capital assets held at the time of death. Table 10 presents our estimates of the total amount of taxes collected under various tax regimes, assuming that the tax changes did not affect the stocks of wealth that households reported in the 1998 Survey of Consumer Finances. (We discuss this unrealistic assumption below.) The first row shows our estimates of the taxes collected by the current (as of 1998) estate tax, with a $\$ 625,000$ estate and gift tax credit. We estimate aggregate revenue of $\$ 16.6$ billion from this tax, with roughly half of that amount coming from estates with values between $\$ 1$ and $\$ 5$ million. (This calculation assumes that the first-to-die spouse in married couples leaves all assets to the surviving spouse.) Our calculations suggest that estates of more than $\$ 10$ million generate 28 percent of current estate tax revenue.

The second row of Table 10 shows our estimates of the revenue from including unrealized capital gains in the income tax base for decedents. Following current tax law, gains of up to $\$ 250,000$ on principal residences are excluded from tax. We do not allow for interactions between the capital gains tax and the estate tax, but rather consider them as alternative policies. If basis step-up at death were eliminated without modifying the estate tax, then a decedent's final income tax payment would include payment for capital gains tax. This tax payment would reduce the decedent's estate, and correspondingly reduce estate tax liability.

We estimate that the revenue yield from eliminating basis step-at-death would have been about $\$ 4.5$ billion per year in 1998 . This estimate is somewhat smaller than the annual revenue 
estimates developed by the Joint Committee on Taxation for 2001-2010, as reported by the Congressional Budget Office (2000). One possible explanation for this divergence is our use of the annuitant mortality table rather than the population mortality table, which reduces our estimated flow of taxable gains by more than one third. Also, the JCT estimates may not assume that married decedents leave all of their appreciated assets to their surviving spouse, as we do in the estimates shown in Table 10 .

Table 10 also shows the distribution of revenues across estates of various sizes. The fraction of the capital gains tax that would be collected from decedents with estates of more than $\$ 10$ million is 29 percent, similar to the share of estate taxes collected from this group.

The last two rows in Table 10 explore the effect of allowing for various exemptions, in addition to the housing exemption, that would reduce capital gains tax liability at death. The third row shows the impact of allowing for a $\$ 100,000$ exemption from capital gains tax liability, and the fourth row shows the effect of a $\$ 500,000$ exemption. We estimate that a $\$ 100,000$ exemption would reduce revenues by $\$ 0.8$ billion per year, while a $\$ 500,000$ exemption would reduce them by $\$ 2.0$ billion per year. These exemptions raise the concentration of tax liability amongst decedents with the highest net worth. With the $\$ 500,000$ exemption, for example, 51 percent of the capital gains tax liability at death is paid by decedents with net worth of $\$ 10$ million or more. The $\$ 100,000$ exemption has a more modest effect. In this case, 35 percent of the capital gains taxes fall on this highest net worth group.

Stratifying households by net worth, as in Table 10, is one way of assessing the distributional effects of different tax policies. It is not, however, the usual approach to 
constructing distribution tables for tax policy analysis. Annual income, rather than net worth, is typically used to stratify households.

Table 11 presents information on the distribution of the same four tax policies that are analyzed in Table 10, but households are now stratified according to adjusted gross income (AGI) rather than net worth. The upper panel in Table 11 shows households categorized by "traditional" AGI, while the lower panel shows households stratified by an imputed income measure that tries to avoid the problems raised by different income-to-value ratios for different types of capital assets. The income measure that we use to stratify households in this case is AGI less all capital income, plus 0.075 times the value of all capital assets. This procedure imputes a 7.5 percent rate of return to all assets. The Joint Committee on Taxation (1993) discusses a number of issues that bear on procedures like this imputation.

The distribution of tax burdens across income categories in Table 11 provides somewhat different insights than the distribution by net worth categories (Table 10). There are also substantial differences between the results in the two panels of Table 11, corresponding to differences between actual and imputed AGI. Since the income measure in the lower panel of Table 11 includes a component that is proportional to net worth, there is a strong correlation between the results in Table 10 and those in the lower panel of Table 11.

To highlight the results, first consider the results on the distribution of estate tax burdens in the first row of the upper panel in Table 11. The table suggests that roughly seven percent of estate taxes are paid by decedents with AGI of $\$ 1$ million or more, while more than half (53 percent) are paid by decedents with AGI of less than $\$ 100,000$. These tabulations show that a 
substantial pool of assets that are taxed under the estate tax are held by households whose current income does not place them at the very top of the income distribution. The pattern is similar for capital gains taxes at death when there is no exemption. Households with incomes of more than $\$ 1$ million pay roughly six percent of these taxes, and households with incomes below $\$ 100,000$ account for 53 percent of these taxes. When we introduce substantial exemptions for appreciated assets, the concentration of capital gains taxes increases. In the case of the $\$ 500,000$ exemption, households with incomes of less than $\$ 100,000$ pay a third of the capital gains taxes, and those with incomes of more than $\$ 1$ million pay a tenth of the taxes.

The concentration of tax liability is quite different when we use the imputed income measure that underlies the distribution table in the lower panel. In this case, more than one quarter of the estate tax is assigned to households with annual imputed income of at least \$1 million, and only eight percent is assigned to households with incomes of less than $\$ 100,000$. The divergence between these results and those in the upper panel of Table 11 highlight the importance of assets with low income flows, but substantial value, in the portfolios of high-networth households. If we used a lower imputed income rate to translate capital assets into income flows, the results in the bottom panel of Table 11 would look more like those in the upper panel. Tables 10 and 11 provide some data on the patterns of estate tax liability and tax liability if gains are taxed at death, but they do not provide direct information on the relative tax burdens on different households under these policies. If one views the current estate tax as an alternative to taxing capital gains at death, then it makes sense to ask how many decedents face larger tax burdens under one tax regime or the other. Recall that the total revenue associated with the 
current estate tax is substantially greater than that associated with the taxation of capital gains at death. The particular policy that we consider is one that taxes all capital gains at death, but allows for a $\$ 250,000$ exemption for gains on a principal residence.

For all 1998 decedents who had no estate tax liability, we estimate that the probability of paying at least $\$ 1000$ in capital gains tax at death is 9 percent. The average capital gains tax liability is $\$ 11,000$ for those who pay at least $\$ 1000$. The chance of facing a capital gains tax bill of $\$ 10,000$ is three percent for those who currently do not pay estate tax. For those who currently pay the estate tax, the probability of facing a capital gains tax bill greater than the current estate tax bill is 17 percent. When we stratify estate-tax-paying decedents by the value of their estate, however, we find that taxing capital gains at death yields tax burdens similar to the current estate tax for decedents with net worth of less than $\$ 1$ million. For this group, conditional on paying estate tax under the current law, 49 percent face a capital gains tax burden that exceeds their current estate tax liability. For those with a capital gains tax bill that is greater than their estate tax bill, the average increase in their tax burden is $\$ 50,100$. The average tax saving for the 51 percent of current estate tax payers with net worth of less than $\$ 1$ million who face higher tax bills under the estate tax than under a capital gains tax is $\$ 43,100$.

Decedents with net worth of more than $\$ 1$ million typically would face smaller tax liabilities if capital gains were taxed at death than they do under the current estate tax. Only five percent of this group would receive a tax reduction if the current estate tax were replaced with an income tax regime that taxed capital gains at death. For the 95 percent that would face a smaller tax burden under the capital gains tax regime, the average tax saving would be $\$ 672,700$. 


\subsection{Carryover Basis vs. Constructive Realization of Gains at Death}

The foregoing analysis considers the case of a capital gains tax on the unrealized gains that are held by decedents at their time of death. An alternative policy that is sometimes discussed in place of taxing capital gains at death ("constructive realization") is requiring that the basis of capital assets held by the decedent "carry over" to the taxpayers who inherit these assets. Leaving aside issues concerned with behavioral response of taxpayers, the tax revenue associated with such a carry-over basis policy would be smaller than the revenue from taxing capital gains at death. This is because gains on assets held by the decedent will be realized at a later date under the carryover basis policy than under the taxation of gains at death. Modeling the behavioral response to such changes in capital gains tax rules is a topic left for further research.

\section{Conclusions and Future Directions}

This paper presents estimates of the revenue effect, and of the distributional patterns, associated with repealing basis step-up at death. The analysis assumes that the pattern of unrealized capital gains and net worth that we observe in the 1998 Survey of Consumer Finances would not be affected by legislative changes. This is clearly in inappropriate assumption, since it is well established that capital gains realizations are quite sensitive to the level of capital gains tax rates. There is even some evidence, such as Auten and Joulfaian (1997), that estate tax rates affect capital gains realizations by older taxpayers. Kopczuk and Slemrod (2000) more generally explore the impact of estate tax rules on patterns of wealth accumulation. The key difficulty is 
deciding what assumptions to make about the sensitivity of capital gains behavior and estate values to potential modifications in the tax code.

Consider the possible effects of reducing the estate tax, and replacing part of the foregone revenue with a tax on unrealized capital gains. Such a tax reform would reduce the lock-in effect that discourages taxpayers from realizing gains at advanced ages, so it would presumably raise revenue from capital gains realizations in years prior to the death of taxpayers. Joulfaian (1991, 2000) and McGarry (2000) explore the potential effect of raising tax rates on behavior, with particular attention to charitable giving at death and to the use of inter vivos giving.

Reducing the estate tax would reduce the incentive for taxpayers to make inter vivos gifts to avoid the estate tax, so it might increase the total amount of wealth held by decedents. This could increase the revenue yield of both the estate tax and the capital gains tax at death. As Bernheim's (1986) analysis suggests, the estate tax rate can affect not just estate tax revenue, but income tax revenue as well.

A related behavioral response concerns portfolio choice. At present, there is a strong incentive for investors to hold assets that generate capital gains rather than dividends or interest income, because the gains on these assets may ultimately escape taxation when the taxpayer dies. If unrealized gains were taxed at the time of death, or if basis were carried forward so that those who inherited the assets would face prospective capital gains tax liability, the incentive for equity investments would be reduced. This could also affect the aggregate pool of unrealized gains that would be subject to taxation at the time of death.

A second broad issue concerns the choice of mortality table for revenue estimation. We 
have used the mortality rates for annuitants throughout our calculations. These mortality rates are lower than the mortality rates for the population at large by as much as thirty percent. This can translate into substantial differences in the estimated revenue effects of changes in the estate tax or in the potential revenues generated by taxing capital gains at the time of death.

Our discussion has focused exclusively on the relative distribution of accrued capital gains and net worth among the decedent population. We have not considered many of the detailed practical issues that arise in implementing constructive realization at death, or in structuring the tax rules for taxing gains with a carry-over basis provision. These issues, which are noted by Gravelle (1994), Burman (1999), and the Congressional Budget Office (2000), include the valuation of gains on assets for which it may be difficult to determine the purchase price, and the potential need for some taxpayers to sell assets in order to raise the capital that is needed to pay capital gains taxes. These are substantive issues that would need to be addressed before making a substantial change in the tax system. 


\section{REFERENCES}

Attanasio, Orazio, and Hilary Hoynes. 2000. "Differential Mortality and Wealth Accumulation," Journal of Human Resources.

Auten, Gerald and David Joulfaian. 1997. "Bequest Taxes and Capital Gains Realizations." Mimeo, U.S. Treasury Department, Office of Tax Analysis.

Bailey, Martin J. 1969. "Capital Gains and Income Taxation." In Arnold Harberger and Martin Bailey, eds., The Taxation of Income from Capital (Washington: The Brookings Institution), 11-49.

Bernheim, B. Douglas. 1987. "Does the Estate Tax Raise Revenue," in L. Summers, ed., Tax Policy and the Economy 1, 113-138.

Bossons, John. 1972. "An Economic Overview of the Tax Reforms." In Proceedings of the Twenty-Third Tax Conference (Toronto: Canadian Tax Foundation), 45-67.

Bossons, John. 1974. "The Effect of Income Tax Reform on Estate Taxes in Canada." Proceedings of the Sixty-Sixth Annual Conference on Taxation, National Tax Association - Tax Institute of America. (Columbus, Ohio: National Tax Association), 148-194.

Burman, Leonard E. 2000. The Labyrinth of Capital Gains Tax Policy. Washington: Brookings Institution.

Congressional Budget Office. 1997. Perspectives on the Ownership of Capital Assets and the Realization of Capital Gains. Washington: CBO Paper.

Cooper, George. 1979. A Voluntary Tax? New Perspectives on Sophisticated Tax Avoidance. Washington: Brookings Institution.

Drew, Christopher, and David Cay Johnston. 1996. "For Wealthy Americans, Death Is More Certain Than Taxes," New York Times 146 (December 22), 1, 30.

Eller, Martha Britton. 1996. "Federal Taxation of Wealth Transfers, 1992-1995," Statistics of Income Bulletin Winter 1996-97, 8-63.

Eller, Martha, Brian Erard, and Chih-Chin Ho. 2000. "The Magnitude and Determinants of Federal Estate Tax Noncompliance." In W. Gale and J. Slemrod, eds., Rethinking Estate and Gift Taxation (Washington: Brookings Institution). 
Finkelstein, Amy, and James Poterba. 2000. "Policyholder Evidence on Selection Effects in the U.K. Individual Annuity Market." Mimeo, MIT Department of Economics.

Gravelle, Jane. 1994. The Economic Effects of Taxing Capital Income. (Cambridge: The MIT Press).

Johnson, Barry W. and Jacob Mikow. 2000. "Elements of Federal Estate Taxation." In W. Gale and J. Slemrod, eds., Rethinking Estate and Gift Taxation (Washington: Brookings Institution).

Johnson, Barry W. and Jacob Mikow. 1999. "Federal Estate Tax Returns, 1995-1997." Statistics of Income Bulletin 19 (Summer), 69-129.

Joulfaian, David. 1991. "Charitable Bequests and Estate Taxes." National Tax Journal 44, 169180.

Joulfaian, David, 1998. "The Federal Estate and Gift Tax: Description, Profile of Taxpayers, and Economic Consequences." OTA Paper 80. Washington: Office of Tax Analysis, U.S. Treasury Department.

Joulfaian, David. 2000. "Estate Taxes and Charitable Bequest by the Elderly." National Tax Journal (forthcoming).

Kennickell, Arthur B., Martha Starr-McCluer, and Brian Surette. 2000. "Changes in U.S. Family Finances at the End of the 1990s: Results from the 1998 Survey of Consumer Finances." Federal Reserve Bulletin (January).

Kopczuk, Wojciech and Joel Slemrod (2000). "The Impact of the Estate Tax on the Wealth Accumulation and Avoidance Behavior of Donors." In W. Gale and J. Slemrod, eds., Rethinking Estate and Gift Taxation (Washington: Brookings Institution).

McGarry, Kathleen, 2000. Inter vivos transfers or bequests? Estate taxes and the timing of parental giving. In J. Poterba, ed., Tax Policy and the Economy 14 (Cambridge: MIT Press).

Mitchell, Olivia S., James M. Poterba, Mark Warshawsky, and Jeffrey R. Brown. 1999. "New Evidence on the Money's Worth of Individual Annuities." American Economic Review 89 (December).

Poterba, James. 2000. "The Estate Tax and After-Tax Investment Returns," in J. Slemrod, ed., Does Atlas Shrug: The Economic Consequences of Taxing the Rich (Cambridge: Harvard University Press, 2000), 333-353. 
Poterba, James. 2001. "Estate and Gift Taxes and Incentives for Inter Vivos Giving in the United States," Journal of Public Economics (forthcoming).

Schmalbeck, Richard. 2000. "Avoiding Federal Wealth Transfer Taxes." In W. Gale and J. Slemrod, eds., Rethinking Estate and Gift Taxation (Washington: Brookings Institution).

Sullivan, Martin A. 2000. "For Richest Americans, Two-Thirds of Wealth Escapes Estate Tax." Tax Notes (April 17), 328-333.

U.S. Congress, Congressional Budget Office. 2000. Budget Options. Washington: Congressional Budget Office.

U.S. Congress, Joint Committee on Taxation. 1993. Methodology and Issues in Measuring Changes in the Distribution of Tax Burdens. Washington: Government Printing Office.

U.S. Congress, Joint Committee on Taxation. 1997. Description and Analysis of Tax Proposals Relating to Savings and Investment (Capital Gains, IRAs, and Estate and Gift Tax). Washington: Government Printing Office.

Wolff, Edward N. 1996. "Commentary." Tax Law Review 51 (Spring), 517-522. 
Table 1: Federal Unified Estate and Gift Tax Rates, 1998

\begin{tabular}{|c|c|}
\hline Taxable Transfer $(\$ 000)$ & Marginal Tax Rate \\
\hline $0-10$ & 20 \\
\hline $10-20$ & 22 \\
\hline $20-40$ & 24 \\
\hline $40-60$ & 26 \\
\hline $60-80$ & 28 \\
\hline $80-100$ & 30 \\
\hline $100-150$ & 32 \\
\hline $150-250$ & 34 \\
\hline $500-750$ & 37 \\
\hline $750-1000$ & 39 \\
\hline $1000-1250$ & 41 \\
\hline $1250-1500$ & 43 \\
\hline $1500-2000$ & 45 \\
\hline $2000-2500$ & 49 \\
\hline $2500-3000$ & 53 \\
\hline $3000-10000$ & 55 \\
\hline $10000-17184$ & $60 *$ \\
\hline$>17184$ & 55 \\
\hline
\end{tabular}

Notes: The 60 percent marginal rate on estates valued at between $\$ 10$ million and $\$ 17.184$ million is a result of the phase-out of infra-marginal tax rates of below 55 percent for estates in this valuation range. Thus, for estates with taxable transfers greater than $\$ 17.184$, the entire transfer is effectively taxed at the 55 percent rate.

Table 2: Transfers Exempted From Estate Tax Under Taxpayer Relief Act of 1997

\begin{tabular}{|c|c|}
\hline 1997 & 600,000 \\
\hline 1998 & 625,000 \\
\hline 1999 & 650,000 \\
\hline $2000-2001$ & 675,000 \\
\hline $2002-2003$ & 700,000 \\
\hline 2004 & 850,000 \\
\hline 2005 & 950,000 \\
\hline $2006+$ & $1,000,000$ \\
\hline
\end{tabular}

Notes: If more than half of a decedent's estate consists of a qualified family-owned business, up to $\$ 675,000$ of the business value may also be deducted from the estate for tax purposes under the Taxpayer Relief Act of 1997. 
Table 3: Number of Households in 1998 Survey of Consumer Finances by Net Worth \& Marital Status of Household Head

\begin{tabular}{|c|c|c|c|}
\hline & Married & Single & All \\
\hline Net Worth $<\$ 500 \mathrm{~K}$ & 1640 & 1287 & 2927 \\
\hline$>\$ 500 \mathrm{~K} \&<\$ 1 \mathrm{M}$ & 247 & 50 & 297 \\
\hline$>\$ 1 \mathrm{M} \&<\$ 5 \mathrm{M}$ & 442 & 87 & 529 \\
\hline$>\$ 5 \mathrm{M} \&<\$ 10 \mathrm{M}$ & 135 & 26 & 161 \\
\hline$>\$ 10 \mathrm{M} \&<\$ 20 \mathrm{M}$ & 136 & 10 & 146 \\
\hline$>\$ 20 \mathrm{M} \&<\$ 50 \mathrm{M}$ & 114 & 17 & 131 \\
\hline$>\$ 50 \mathrm{M} \&<\$ 100 \mathrm{M}$ & 58 & 6 & 64 \\
\hline$>\$ 100 \mathrm{M} \&<\$ 500 \mathrm{M}$ & 39 & 10 & 49 \\
\hline$>\$ 500 \mathrm{M}$ & 1 & 0 & 4305 \\
\hline All & 2812 & 1493 & \\
\hline
\end{tabular}

Notes: The five highest net worth households headed by a married couple in the SCF sample have net worth of 501, 452, 452, 434, \& 404 million dollars. The highest net worth households headed by a single person in the sample have net worth of $356,312,223,176, \& 163$ million dollars. The net worth threshold to be included in the 1998 Eorbes 400 was $\$ 500$ million.

Table 4: Estimated Estate Tax Revenue from Single and Married Households 1998

\begin{tabular}{|c|c|c|c|c|c|}
\hline \multirow[t]{3}{*}{ 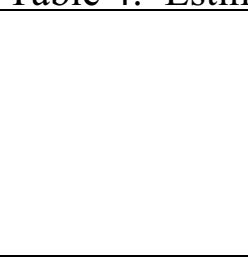 } & \multirow{3}{*}{$\begin{array}{c}\text { Single } \\
\text { Households }\end{array}$} & \multicolumn{4}{|c|}{ Married Households } \\
\hline & & \multicolumn{2}{|c|}{$\begin{array}{l}\text { Bequeath everything to } \\
\text { surviving spouse }\end{array}$} & \multicolumn{2}{|c|}{$\begin{array}{c}\text { Bequeath none of estate to } \\
\text { surviving spouse }\end{array}$} \\
\hline & & $\begin{array}{c}\text { One spouse } \\
\text { dies }\end{array}$ & $\begin{array}{c}\text { Both spouses } \\
\text { die }\end{array}$ & $\begin{array}{c}\text { One spouse } \\
\text { dies }\end{array}$ & $\begin{array}{c}\text { Both spouses } \\
\text { die }\end{array}$ \\
\hline $\begin{array}{c}\text { Total } \\
\text { Estate Tax } \\
\text { (\$billion) }\end{array}$ & 15.98 & 0 & .64 & 26.07 & .51 \\
\hline $\begin{array}{c}\text { \# of Taxable } \\
\text { Returns } \\
\text { (thousands) }\end{array}$ & 25.15 & 0 & 1.51 & 35.81 & .52 \\
\hline
\end{tabular}

Notes: Estimated estate tax is calculated using the average funeral expense, executor's commission, lawyer's fee, charitable deduction, and state death tax credit for taxable returns for each gross estate class for 1998 filers supplied by Barry Johnson and Jacob Mikow.

It is assumed that assets are divided equally among spouses. 
Table 5: Estate Tax Returns Filed in 1998, by Gross Estate and Marital Status

\begin{tabular}{|c|c|c|c|c|c|c|}
\hline & \multicolumn{3}{|c|}{ Married } & \multicolumn{3}{|c|}{ Non-Married } \\
\hline & $\begin{array}{c}\text { Fraction of } \\
\text { returns that } \\
\text { pay any tax }\end{array}$ & $\begin{array}{c}\text { Gross } \\
\text { Estate } \\
\text { Value }\end{array}$ & $\begin{array}{c}\text { Net Estate } \\
\text { Tax Paid }\end{array}$ & $\begin{array}{c}\text { Fraction of } \\
\text { returns that } \\
\text { pay any tax }\end{array}$ & $\begin{array}{c}\text { Gross } \\
\text { Estate } \\
\text { Value }\end{array}$ & $\begin{array}{c}\text { Net Estate } \\
\text { Tax Paid }\end{array}$ \\
\hline All returns & $13.3 \%$ & $\$ 83.8 \mathrm{~B}$ & $\$ 3.7 \mathrm{~B}$ & $75.9 \%$ & $\$ 90.0 \mathrm{~B}$ & $\$ 16.7 \mathrm{~B}$ \\
\hline$\$ .6-1 \mathrm{M}$ & 5.3 & 15.1 & .0 & 62.8 & 23.2 & .9 \\
\hline $1-2.5$ & 14.2 & 25.9 & .5 & 91.7 & 27.5 & 4.4 \\
\hline $2.5-5$ & 30.5 & 13.6 & .7 & 92.4 & 12.7 & 3.5 \\
\hline $5-10$ & 42.3 & 8.9 & .6 & 94.9 & 9.2 & 2.8 \\
\hline $10-20$ & 53.2 & 6.6 & .5 & 93.5 & 6.3 & 2.0 \\
\hline $20+$ & 74.9 & 13.6 & 1.3 & 93.5 & 11.0 & 3.1 \\
\hline
\end{tabular}

Source: Data supplied by Barry Johnson and Jacob Mikow.

Table 6: Net Worth of Members of Forbes 400 Decedents, 1995-1998

\begin{tabular}{|c|c|c|c|c|}
\hline & \multicolumn{2}{|c|}{ All Members of Forbes 400} & \multicolumn{2}{c|}{ Single Members of Forbes 400} \\
\hline & Number & Net Worth & Number & Net Worth \\
\hline 1998 & 7 & $\$ 16.3$ billion & 1 & $\$ 4.0$ billion \\
\hline 1997 & 5 & 4.2 & 2 & 1.7 \\
\hline 1996 & 6 & 5.3 & 2 & 1.3 \\
\hline 1995 & 10 & 8.0 & 4 & 5.0 \\
\hline
\end{tabular}

Source: Forbes magazine, various issues. Total net worth for the Forbes 400 rose from $\$ 357$ billion in 1995 to $\$ 738$ billion in 1998. 
Table 7: Estimated Estate Tax Revenue Under Various Estate and Gift Tax Credits and Exemptions, \$1998 Billion

\begin{tabular}{|c|c|c|c|}
\hline \multicolumn{4}{|c|}{ Weighted Average Algorithm for Calculating Estate Tax from Married Decedents } \\
\hline & Exemption $=\$ 625 \mathrm{~K}$ & Exemption $=\$ 1 \mathrm{M}$ & Exemption $=\$ 3 \mathrm{M}$ \\
\hline $\begin{array}{l}\text { Deductions Under } \\
\text { Current Tax Law }\end{array}$ & 27.38 & 23.61 & 12.82 \\
\hline $\begin{array}{l}\text { Allowed to Deduct } \\
\$ 1 \mathrm{M} \text { in Principal } \\
\text { Residence }\end{array}$ & 23.73 & 20.68 & 11.45 \\
\hline $\begin{array}{l}\text { Allowed to Deduct } \\
\text { both } \$ 1 \mathrm{M} \text { Principal } \\
\text { Residence \& } \\
\$ 3 \mathrm{M} \text { in Business }\end{array}$ & 21.23 & 18.33 & 10.26 \\
\hline \multicolumn{4}{|c|}{ Assume Married Decedent Leaves Everything to Spouse } \\
\hline & Exemption $=\$ 625 \mathrm{~K}$ & Exemption $=\$ 1 \mathrm{M}$ & Exemption $=\$ 3 \mathrm{M}$ \\
\hline $\begin{array}{l}\text { Deductions Under } \\
\text { Current Tax Law }\end{array}$ & 16.62 & 13.75 & 6.67 \\
\hline $\begin{array}{l}\text { Allowed to Deduct } \\
\$ 1 \mathrm{M} \text { in Principal } \\
\text { Residence }\end{array}$ & 13.95 & 11.72 & 5.78 \\
\hline $\begin{array}{l}\text { Allowed to Deduct } \\
\text { both } \$ 1 \mathrm{M} \text { Principal } \\
\text { Residence \& } \\
\$ 3 \mathrm{M} \text { in Business }\end{array}$ & 12.84 & 10.67 & 5.29 \\
\hline \multicolumn{4}{|c|}{ Assume Assets Divided Evenly \& Married Decedent Leaves Nothing to Spouse } \\
\hline & Exemption $=\$ 625 \mathrm{~K}$ & Exemption $=\$ 1 \mathrm{M}$ & Exemption $=\$ 3 \mathrm{M}$ \\
\hline $\begin{array}{l}\text { Deductions Under } \\
\text { Current Tax Law }\end{array}$ & 42.56 & 35.68 & 17.06 \\
\hline $\begin{array}{l}\text { Allowed to Deduct } \\
\$ 1 \mathrm{M} \text { in Principal } \\
\text { Residence }\end{array}$ & 36.20 & 30.62 & 15.12 \\
\hline $\begin{array}{l}\text { Allowed to Deduct } \\
\text { both } \$ 1 \mathrm{M} \text { Principal } \\
\text { Residence \& } \\
\$ 3 \mathrm{M} \text { in Business }\end{array}$ & 31.36 & 26.26 & 13.21 \\
\hline
\end{tabular}

Notes: Estimated estate tax is calculated using the average funeral expense, executor's commission, lawyer's fee, charitable deduction, and state death tax credit for taxable returns for each gross estate class for 1998 filers supplied by Barry Johnson and Jacob Mikow. The top panel is a weighted average of the bottom two panels. See text for details. 
Table 8: Unrealized Capital Gains in 1998 Insurance-Augmented Net Worth of Decedent, By InsuranceAugmented Net Worth (\$billion)

\begin{tabular}{|c|c|c|c|c|c|c|c|}
\hline (2) & All & $<250 \mathrm{~K}$ & $\begin{array}{l}250- \\
500 \mathrm{~K}\end{array}$ & $\begin{array}{c}500- \\
1000 \mathrm{~K}\end{array}$ & $1-5 \mathrm{M}$ & $5-10 \mathrm{M}$ & $10 \mathrm{M}+$ \\
\hline $\begin{array}{l}\text { Value of Estate } \\
\text { (\$billion) }\end{array}$ & 118 & 32.6 & 18.7 & 9.7 & 36.1 & 9.6 & 11.7 \\
\hline $\begin{array}{l}\text { Unrealized } \\
\text { Capital Gain } \\
\text { (\$billion) }\end{array}$ & 42.8 & 11.8 & 6.3 & 3.3 & 12.5 & 2.3 & 6.6 \\
\hline & \multicolumn{7}{|c|}{ Share of Total Assets (in percent): } \\
\hline $\begin{array}{c}\text { Primary } \\
\text { Residence }\end{array}$ & $29.7 \%$ & $59.4 \%$ & $37.9 \%$ & $25.1 \%$ & $15.4 \%$ & $4.6 \%$ & $3.1 \%$ \\
\hline Other Real Estate & 10.0 & 2.2 & 17.2 & 14.8 & 13.3 & 9.3 & 6.9 \\
\hline $\begin{array}{c}\text { Business (active) } \\
\text { \& Farm }\end{array}$ & 7.2 & 0.4 & 0.7 & 1.0 & 5.1 & 5.2 & 49.4 \\
\hline Other Business & 1.0 & 0.0 & 0.2 & 0.7 & 1.7 & 0.6 & 3.0 \\
\hline $\begin{array}{c}\text { Public Stock } \\
\text { (directly held) \& } \\
\text { Mutual Funds }\end{array}$ & 19.1 & 3.9 & 10.4 & 19.8 & 30.0 & 41.2 & 22.4 \\
\hline & \multicolumn{7}{|c|}{ Share of Total Unrealized Capital Gain (in percent): } \\
\hline $\begin{array}{c}\text { Primary } \\
\text { Residence } \\
\end{array}$ & 54.7 & 100.1 & 83.1 & 46.0 & 35.2 & 10.2 & 3.6 \\
\hline Other Real Estate & 13.1 & 2.8 & 11.3 & 31.9 & 19.8 & 26.0 & 6.9 \\
\hline $\begin{array}{c}\text { Business (active) } \\
\text { \& Farm }\end{array}$ & 15.9 & 0.6 & 1.4 & 1.7 & 11.4 & 17.2 & 72.3 \\
\hline Other Business & 2.1 & 0.0 & 0.4 & 1.9 & 3.8 & 2.2 & 4.1 \\
\hline $\begin{array}{c}\text { Public Stock } \\
\text { (directly held) \& } \\
\text { Mutual Funds }\end{array}$ & 14.1 & -3.5 & 3.8 & 18.4 & 29.9 & 44.4 & 13.1 \\
\hline
\end{tabular}

Notes: Estate value includes face value of life insurance. Basis and unrealized capital gain are reported for directly held stock, mutual funds, business holdings, and real estate. Bonds, vehicles, and collectibles are assumed to have no accrued capital gains. The expected value of estates and unrealized capital gains is calculated by applying 1998 annuitant mortality rates, as described in the text, to the sample of households in the 1998 SCF (appropriately weighted to reflect the population). It is assumed a decedent transfers his/her full estate to a surviving spouse. Such inter-spousal transfers are not included in the estate totals reported above. 
Table 9: Fraction of Decedent Households, by Estate Value, with Unrealized Capital Gains Comprising $<25,25-50,50-75$, and $>75 \%$ of Estate, 1998

\begin{tabular}{|c|c|c|c|c|c|c|c|}
\hline \multirow{2}{*}{$\begin{array}{c}\text { Unrealized Gains } \\
\text { as a Percent of } \\
\text { Estate }\end{array}$} & \multicolumn{7}{|c|}{ Insurance-Augmented Net Worth } \\
\hline & $\begin{array}{c}\text { All } \\
(>0)\end{array}$ & $0-250 \mathrm{~K}$ & $\begin{array}{l}250- \\
500 \mathrm{~K}\end{array}$ & $\begin{array}{r}500- \\
1000 \mathrm{~K} \\
\end{array}$ & $1-5 \mathrm{M}$ & $5-10 \mathrm{M}$ & $10 \mathrm{M}+$ \\
\hline$<25$ & $49 \%$ & $51 \%$ & $34 \%$ & $52 \%$ & $48 \%$ & $76 \%$ & $21 \%$ \\
\hline $25-50$ & 22 & 21 & 32 & 11 & 18 & 14 & 24 \\
\hline $50-75$ & 16 & 15 & 18 & 18 & 31 & 8 & 36 \\
\hline$>75$ & 13 & 13 & 16 & 19 & 3 & 2 & 18 \\
\hline Total & 100 & 100 & 100 & 100 & 100 & 100 & 100 \\
\hline
\end{tabular}

Notes: Authors' tabulations from 1998 Survey of Consumer Finances. Value of estate is decedent's net worth plus face value of life insurance. 
Table 10: Distribution of Various Capital Income Taxes by Size of Insurance-Augmented Net Worth, 1998 (\$ billion)

\begin{tabular}{|c|c|c|c|c|c|c|c|}
\hline & \multicolumn{7}{|c|}{ Estate Size } \\
\hline $\begin{array}{c}\text { Current } \\
\text { Estate Tax }\end{array}$ & 16.62 & 0.00 & 0.00 & 0.27 & 8.50 & 3.22 & 4.63 \\
\hline $\begin{array}{c}\text { Tax Capital Gains } \\
\text { at Death } \\
\text { (no exemption) }\end{array}$ & 4.53 & 0.09 & 0.25 & 0.42 & 2.02 & 0.43 & 1.32 \\
\hline $\begin{array}{c}\text { Tax Capital Gains } \\
\text { at Death (\$100K } \\
\text { gain exemption) }\end{array}$ & 3.75 & 0.00 & 0.05 & 0.26 & 1.74 & 0.39 & 1.31 \\
\hline $\begin{array}{c}\text { Tax Capital Gains } \\
\text { at Death (\$500K } \\
\text { gain exemption) }\end{array}$ & 2.54 & 0.00 & 0.00 & 0.02 & 0.95 & 0.28 & 1.29 \\
\hline
\end{tabular}

Note: Calculations of net worth (estate size) include decedent's net worth plus face value of life insurance. The expected value of estates and unrealized capital gains is calculated by applying 1998 mortality numbers (interpolation of 1983 and 2000 Annuitant Life Tables) to the sample of households in the 1998 SCF (appropriately weighted to reflect the population). The probability of death across spouses is assumed to be independent. It is assumed a decedent transfers his/her full estate to a surviving spouse. Thus, there is no capital gains tax at death and no estate tax liability if there is a surviving spouse. Estates are assumed to be able to exempt up to $\$ 250 \mathrm{~K}$ in capital gains from the principal residence when calculating taxable capital gains at death. 
Table 11: Distribution of Taxes on Capital Assets at Time of Death, by Income Class, 1998 (\$ billion)

\begin{tabular}{|c|c|c|c|c|c|c|c|}
\hline & \multicolumn{7}{|c|}{ Adjusted Gross Income } \\
\hline & All & $<50 \mathrm{~K}$ & $\begin{array}{c}50- \\
100 \mathrm{~K} \\
\end{array}$ & $\begin{array}{r}100- \\
250 \mathrm{~K}\end{array}$ & $\begin{array}{c}250- \\
500 \mathrm{~K}\end{array}$ & $\begin{array}{c}500- \\
1000 \mathrm{~K}\end{array}$ & $1 \mathrm{M}+$ \\
\hline $\begin{array}{c}\text { Current } \\
\text { Estate Tax }\end{array}$ & 16.62 & 5.15 & 3.66 & 3.51 & 2.41 & .78 & 1.10 \\
\hline $\begin{array}{c}\text { Tax Capital Gains } \\
\text { at Death } \\
\text { (no exemption) }\end{array}$ & 4.53 & 1.45 & .97 & .94 & .80 & .11 & .26 \\
\hline $\begin{array}{l}\text { Tax Capital Gains } \\
\text { at Death }(\$ 100 \mathrm{~K} \\
\text { gain exemption) }\end{array}$ & 3.75 & .95 & .79 & .86 & .79 & .10 & .26 \\
\hline \multirow[t]{3}{*}{$\begin{array}{l}\text { Tax Capital Gains } \\
\text { at Death }(\$ 500 \mathrm{~K} \\
\text { gain exemption })\end{array}$} & 2.54 & .42 & .42 & .61 & .75 & .09 & .25 \\
\hline & \multicolumn{7}{|c|}{ Imputed Income } \\
\hline & All & $<50 \mathrm{~K}$ & $\begin{array}{c}50- \\
100 \mathrm{~K} \\
\end{array}$ & $\begin{array}{l}100- \\
250 \mathrm{~K}\end{array}$ & $\begin{array}{l}250- \\
500 \mathrm{~K}\end{array}$ & $\begin{array}{c}500- \\
1000 \mathrm{~K} \\
\end{array}$ & $1 \mathrm{M}+$ \\
\hline $\begin{array}{c}\text { Current } \\
\text { Estate Tax }\end{array}$ & 16.62 & .40 & .94 & 5.18 & 5.17 & .42 & 4.51 \\
\hline $\begin{array}{c}\text { Tax Capital Gains } \\
\text { at Death } \\
\text { (no exemption) }\end{array}$ & 4.53 & .42 & .60 & .95 & 1.15 & .11 & 1.29 \\
\hline $\begin{array}{l}\text { Tax Capital Gains } \\
\text { at Death ( } \$ 100 \mathrm{~K} \\
\text { gain exemption) }\end{array}$ & 3.75 & .13 & .38 & .77 & 1.08 & .11 & 1.28 \\
\hline $\begin{array}{l}\text { Tax Capital Gains } \\
\text { at Death }(\$ 500 \mathrm{~K} \\
\text { gain exemption) }\end{array}$ & 2.54 & .01 & .06 & .32 & .81 & .09 & 1.25 \\
\hline
\end{tabular}

Notes: Imputed income adds non-capital income to an imputed income stream from assets (.075 multiplied by the stock of assets). The expected value of estates and unrealized capital gains is calculated by applying 1998 mortality numbers (interpolation of 1983 and 2000 Annuitant Life Tables) to the sample of households in the 1998 SCF (appropriately weighted to reflect the population). The probability of death across spouses is assumed to be independent. It is assumed a decedent transfers his/her full estate to a surviving spouse. Thus, there is no capital gains tax at death and no estate tax liability if there is a surviving spouse. Estates are assumed to be able to exempt up to $\$ 250 \mathrm{~K}$ in capital gains from the principal residence when calculating taxable capital gains at death. 